\title{
The Influence of Packaging Elements on Buying Behaviour for Convenience Goods amongst Customers
}

\author{
Faith Tinonetsana, Darry Penceliah \\ Durban University of Technology, Durban, South Africa \\ pencelid@dut.ac.za
}

\begin{abstract}
The role of packaging has changed with the move to self-service retail formats. Marketers have transformed packaging to become one of the major promoting tools to products. There was a necessity to explore packaging and its elements in order to understand which of these elements influence international university students purchase decisions. Thus, this paper seeks to determine the relationship between international university students' buying behaviour and package elements through linear regression analysis. A quantitative, non-probability research approach was employed. A convenience sample was used to select study 400international students from two South African universities. Research findings reveal that international students' perception of packaging elements influence their buying behaviour. The results also show that there is a significant relationship between consumer perception and students buying behaviour. Findings also reveal that there is a significant relationship between consumer buying behaviour and seven predictor variables; colour, graphics, packaging technology, label information, brand name, time pressure and level of involvement. It is thus imperative for the marketers to understand that packaging elements have various influences on the consumer depending on context and on product. If the package elements are properly combined, the package will be more attractive and attention grabbing.
\end{abstract}

Keywords: Buying behaviour, convenience goods, packaging elements, international university students

\section{Introduction}

Packaging has various functions which include the capacity of positioning brands on distinctive and attractive positions that arouse consumer buying decision; it communicates persuasive and descriptive information about brands (Mutsikiwa, Marumbwa \& Mudondo, 2013). Wells, Farley and Armstrong (2007) state that besides using package to protect products during storage and selling against damage and smudge, in addition, it is being used as a marketing means in building and reinforcement of brand equity. However, Kotler and Keller (2012) point out that package offers customers a logo that is visible allowing them to tell the product in the package quickly. Packaging is a dependable basis of brand information. It carries information on quality, quantity, pricing, information about direction of use and ingredients. Inappropriate packaging designs could also emanate from the fact that packaging differs around the world. Kotler and Keller (2012) are of the view that understanding how the consumer makes decisions amongst different products can give producers an upper hand over rivals. Organisations can utilise this information deliberately with a specific end goal to sell the right products at the correct time to the right people at the right place. The value of packaging tool to communicate with consumers is increasing. To understand how to communicate with consumers, it is vital that producers get adequate information on the psychology of consumers. This is important to comprehend the reaction of consumers to packaging of fundamental products (Jafari, Nia, Salehi \& Zahmatkesh, 2013). The overall purchase decision is affected by the nature of relationship between the packaging elements and consumer behaviour. Hence, while marketers and businesses should understand the process a consumer goes through to make a decision, they should equally explore and understand the influence of packaging on the ultimate purchase decision. However, literature in this regard is scanty and hence, the study focuses on how packaging elements influence consumer buying behaviour from an international university students' perspective to enable evaluation of local packaging to best international standards. Packaging must be sufficiently orchestrated for its marketing function to assist in selling the product by triggering interest and presenting the product positively to the intended consumers (Lee, 2010). As stores are drawing closer to a self-administration design and diverse products are found on store shelves, sellers assume a less imperative part in communicating to consumers by leaving the product information to be communicated to consumers by the package. Thus, the significance of packaging rises daily (Muruganantham \& Bhakat, 2013). There was a necessity to explore packaging and its elements in order to understand which of these elements influence international university students purchase decisions in South Africa. 


\section{Literature Review}

Understanding consumer behaviour: Consumer behaviour involves physical, mental and emotional activities in which individuals select, buy and utilise goods to fulfil their needs (Gilaninia, Ganjinia \& Moradi, 2013; Schiffman \& Kanuk, 2007). On a similar note, Esitiri, Hasangholipour, Yazdani, Nejad and Rayej (2010) state that consumer purchasing behaviour is a mental introduction describing a consumers' way to deal with settling on a decision. However, the final decision that a consumer makes is affected by various factors and contexts, hence, consumers behave differently in any given scenario. It is essential for organizations that intend to survive and be successful to see how individuals carry on in a purchasing process. Retaining customers, customer relationship marketing, customer value and lifetime value of customers are urgent angles that organizations have to take into consideration through marketing (Du Plessis, Rousseau, Boshoff, Ethlers, Englebrecht, Joubert \& Sanders, 2011). Marketers are constantly interested in understanding consumer behaviour as this knowledge provides the marketer with information on how consumers behave. This includes how they think, feel and choose from many like products, brands and so on as well as how consumer behaviour is influenced by their surroundings, reference groups, family, and salespersons (Brosekhan \& Velayutham, 2014). The buying behaviour exhibited by a consumer is as a result of cultural, social, personal and psychological factors. It is important for marketers to try to comprehend this behaviour even though it is complex and most of the factors that influence it are uncontrollable and beyond the hands of marketers (Rizvi \& Elahi, 2013). Principal reasons which impact buying on impulse are mental stimuli, advertising, and package is identified as one of the inducements. It is therefore important to understand consumer behaviour over time given the radical changes taking place in the field of marketing.

Consumers examine their desires in light of the messages obtained by means of the package and in the event that package misrepresents the benefits of the product, this is when the consumers experience unfulfilled desires that result in disappointment and dissatisfaction. The package shape is another critical paradigm for assessment in this stage. Different shapes of packaging, considering the demands and shapes of the product, can assume an essential part in this stage. The results by Warlop, Ratneshwar, Osselaer and Stijn, (2005) demonstrate that diverse packaging components, through helping the remembrance of perceived quality of products, play an essential part in the review and repurchase of products. Lake (2009) affirms that when buying high involvement goods, each stage in the decision-making process is useful and only the last two stages are important in products with low involvement products. The process of decision making in consumer purchasing behaviour demonstrates that packaging ought not just to increase consumers' consideration or convince consumers to purchase products; it rather ought to develop positive assessments after purchase and make sure that consumers make repeated purchases. Metcalf, Hess, Danes and Singh (2012) are of the opinion that packaging ought to be intended for consumer ease-of-use, convenience and simplicity of carrying the product.

Packaging elements: Wells, Farley and Armstrong (2007) report that the majority (73\%) of participants confirm that they depend on packaging when making purchase decisions. On a similar note, Jafari et al. (2013)state that the International Institute for Point of Purchase Advertising (IIPPA) report states that approximately $72 \%$ of buying decisions are done right at the purchase point. Philips and Bradshaw (2011 cited in Jafari et al., 2013) state that impulsive purchase that take place in supermarkets amount to $51 \%$ of all purchases. In America, buyers spend approximately 35 minutes in a store; where they encounter about 6300 products and have to make a choice on average of only 14 of them (Salahshour \& Feyz, 2010). Kotler and Keller (2012) agree to this finding as they point out that consumers encounter over 20,000 products within a 30-minute shopping period. Since a consumer has to pass through many products in a short space of time it therefore means that marketers must design an attractive package which will draw consumer's attention. This is supported in a study by Zeyghami, Rezaei, Asadi and Davoodabadi (2011) whose findings affirm that 60 percent of purchase made in a day are not planned and above $20 \%$ of these decisions are triggered by the way products are packaged. This suggests that the role that packaging has on buying behaviour cannot be underestimated. It is in the interest of the businesses and marketers to give packaging the attention it deserves given its potential to invoke and influence buying decisions.

Kuvykaite, Dovaliene and Navickiene (2009) state that memory of a package is improved for non-verbal stimuli if the picture is placed to the left and is improved for verbal stimuli if the information is scribed to the 
right side of the packaging. A qualitative study done by Otterbing, Shams, Wastlund and Gustafsson (2013) on textual and pictorial elements of packaging, indicates that pictorial elements like photography of product ought to be put on the left side of the packaging so as to maximize customer memory. This certainly demonstrates that engaging quality of graphics, as well as the best possible arrangement of pictorial and literary component of packaging is fundamental to be recognized by customers. Alervall and Saied (2013) report that seventy-five percent (majority) of the consumers who were interviewed said that the main visual element that influenced their emotions was colour. The respondents said colour has a substantial influence on human instincts and human psychology. This is also supported by Wu, Bao, Song and Hu (2009) who contend that colours bring strong symbolic significance and it impact consumers' psychological and visual feelings. Ahmadi, Bahrami and Ahani (2013) suggest that the customer's eagerness to purchase a product rises if the product is exhibited in smaller packages. In another study the outcomes were those packaging impact consumers' choices while size and shape usually influence respondents buying behaviour (Kariuki \& Karugu 2014). Ares, Besio, Gimenez and Deliza (2010) state that the shape of a package, be it square or round does not influence buying decisions for the respondents. Sioutis (2011) asserts that technology in packaging which represents convenience is the most significant element in influencing buying decisions. Wills, Schmidt, Pillo-Blocka and Cairns (2009) on the buyer state of mind towards food information found that additional information given on the packaging ought to be proper as it influences consumer nutritional decisions.

Hollywood, Wells, Armstrong and Farley (2013) affirm that consumers usually read information on packaging when they need to purchase a substitute product, when the product they normally purchase is not available. Furthermore, Adam and Ali (2014) carried out a study and found that country of origin is positively correlated with consumer purchasing behaviour. As identified by the study, consumers regularly check country of origin before purchasing. In a study on university students by Mutsikiwa et al. (2013) the results reveal that brand name has a significant relationship with purchase decisions of university students. Silayoi and Speece (2007) suggest that time pressure is a major factor in influencing the consumers' buying behaviour. Results show that consumers who are under time pressure use visual elements when selecting products. On the other hand, verbal elements are found to have strong influence when consumers are not under time pressure. Venter, Merwe, Beer, Bosman and Kempen (2011) investigated an example of perception of South African consumers of food packaging. Results found that respondents generally perceive packaging basing on its physical and functional attributes through spontaneous awareness. This indicates that verbal attributes were essential, as respondents considered some information as critical either for their healthiness or for determining whether to buy the product.

\section{Methodology}

The data for the study were collected from international students in two universities in South Africa using a quantitative research approach through a structured questionnaire.

Sample: The sample comprised full-time international students from University of Fort Hare (UFH) and Durban University of Technology (DUT). A non-probability convenient sampling technique using a crosssectional survey was used to select respondents based on their availability. DUT was intentionally selected since the researcher is based at DUT. Furthermore, both DUT and UFH enrol a higher number of international students, especially, from Zimbabwe and Nigeria because of the scholarships they are awarded from their home country.

Measuring instrument: A Likert-scale structured questionnaire was used to measure latent constructs, in this case, consumer behaviour. The questionnaire was designed in a manner that addressed the study, hence the measuring instrument managed to measure what had to be measured. These ordinal scales measure levels of agreement/disagreement on a continuum from strongly disagree to strongly agree, thus making assumptions that behaviour can be measured. This is necessary to uncover degrees of opinion of the respondents. A pre-test was done on a small group of university students to eliminate discrepancy and lack of clarity in some questions that affect efficiency and effectiveness.

Data collection and procedure: A self-reported questionnaire was distributed to a convenient sample. An enclosed letter, clearly indicating the purpose of the study, was attached to the questionnaire. Of the 400 
questionnaires that were distributed, 397 were returned, which were used for the data analysis. Various ethical considerations were adhered to in administering the questionnaire. The students' rights to anonymity, confidentiality and privacy were respected. Statistical Package for Social Scientists (SPSS) was used for data analyses. Regression analysis was used to estimate relationship between consumer buying behaviour and the packaging elements.

Reliability and validity: The two most important aspects of precision are reliability and validity. The reliability of the questionnaire is computed by taking several measurements on the same subjects by computing the Cronbach alpha coefficient. Reliability value of 0.70 is an acceptable coefficient though lower thresholds are often reported in the literature, depending upon the nature and context of the study (Tavakol \& Dennick, 2011). Generally, higher reliability coefficients are indicative of satisfactory reliability of a research instrument. The results show that reliability scores for all sections (approximate or) exceed the recommended Cronbach's alpha value. This therefore indicates a degree of acceptable, consistent scoring for these sections of the research.

Factor analysis is used to find latent variables or factors among observed variables (Tustin, Lingthelm, Martins\& van Wyk, 2005). In marketing research, there may be a large number of variables, most of which are correlated (Maholtra, 2006). In this case, factor analysis could be used to reduce the number of variables to a manageable level for the purpose of composite analysis and interpretation. However, for factor analysis to be appropriate, the variables must be correlated. Hence, this study employed factor analysis. The value of the KMO statistic was above 0.5 for the packaging elements considered in the study, hence, it was considered appropriate for factor analysis. The Bartlett's Test of Sphericity is considered to be significant therefore, allows for the factor analysis procedure. Both KMO and Bartlett's test are presented in Table 1.

Table 1: The Kaiser-Meyer-0lkin (KMO) and Bartlett's test of sampling adequacy

\begin{tabular}{lll}
\hline KMO and Bartlett's Test & & \\
\hline \multicolumn{3}{l}{ Kaiser-Meyer-Olkin (KMO) Measure of Sampling Adequacy. } \\
& Approx. Chi-Square & 0.846 \\
\multirow{3}{*}{ Bartlett's Test of Sphericity } & Df & 1160.759 \\
& Sig. & 28 \\
& 0.000 \\
\hline
\end{tabular}

\section{Results and Discussion}

There were 397 responses from the targeted university students, representing a 99.3\% response rate. The analysis of respondent characteristics is reflected in Table 2.

Table 2: Characteristics of respondent

\begin{tabular}{|c|c|c|c|c|}
\hline Variable & Category & Frequency & Frequency (\%) & Cumulative (\%) \\
\hline & $20-24$ & 217 & 54.7 & 54.7 \\
\hline Age & $25-29$ & 151 & 38.0 & 92.7 \\
\hline respondent & $\geq 30$ & 29 & 7.3 & 100 \\
\hline Gender & Male & 164 & 41.3 & 41.3 \\
\hline respondent & Female & 233 & 58.7 & 100 \\
\hline \multirow{4}{*}{ Education level } & Diploma & 196 & 49.3 & 49.3 \\
\hline & Honours/ BTech & 129 & 32.5 & 81.8 \\
\hline & Masters & 45 & 11.4 & 93.2 \\
\hline & Doctorate & 27 & 6.8 & 100 \\
\hline
\end{tabular}

Characteristics of respondents: The results show that most of the respondents (54.7\%) were in the $20-24$ years' category, while $38.0 \%$ and $7.3 \%$ were in the $25-29$ years and above 30 years respectively. Men and women have different shopping strategies, suggesting that the way they perceive packaging elements when they make purchasing decisions varies. Kuvykaite et al. (2009) found that the visual elements were most important for women, whilst, men prefer verbal elements. Thus, it was therefore important to consider 
gender in this study, which could substantiate trends in the analyses that follow below. Majority of the respondents (58.7\%) were females while $41.3 \%$ were males. Following Kuvykaite et al. (2009) argument above, results could be skewed towards visual elements as more women participated in this study. The section that follows explains the regression analysis results.

Regression analysis: The aim of the regression analysis in the study was to investigate relationship existing between the dependent variable (consumer buying behaviour) and the predictor variables such as packaging elements, time pressure and level of involvement. The specified regression model equation takes the following form:

$\mathrm{CBB}=\beta_{0}+\beta_{1} X_{1}+\beta_{2} X_{2}+\beta_{3} X_{3}+\beta_{4} X_{4}+\beta_{5} X_{5}+\beta_{6} X_{6}+\beta_{7} X_{7}+\beta_{8} X_{8}+\beta_{9} X_{9}+\beta_{10} X_{10}+\beta_{11} X_{11}+$ $\mu \ldots$ equation 1

Where: CBB: Consumer buying behaviour

$\beta_{0}$ : Constant

$\beta_{1}-\beta_{11}$ : Slope parameters of the model

$\mathrm{X}_{1}$ : Colour of packaging (CL)

$\mathrm{X}_{2}$ : Size and shape (SS)

$\mathrm{X}_{3}$ : Graphics (GP)

$\mathrm{X}_{4}$ : Packaging material (PM)

$\mathrm{X}_{5}$ : Packaging technology (PT)

$\mathrm{X}_{6}$ : Nutritional information (NI)

$\mathrm{X}_{7}$ : Label information (LI)

$\mathrm{X}_{8}$ : Country of origin (CO)

$\mathrm{X}_{9}$ : Brand name (BN)

$\mathrm{X}_{10}$ : Level of involvement (LI)

$\mathrm{X}_{11}$ : Time pressure (TP)

$\mu$ : Error term

For this paper linear regression analysis was used to estimate relationship between consumer buying behaviour and the packaging elements. The predictor variables (packaging elements) and the specified regression model equation took the following form:

$C B B=\beta_{0}+\beta_{1}(C L)+\beta_{2}(S S)+\beta_{3}(G P)+\beta_{4}(P M)+\beta_{5}(P T)+\beta_{6}(N I)+\beta_{7}(L I)+\beta_{8}(C O)+\beta_{9}(B N)+\beta_{10}(I L)+$

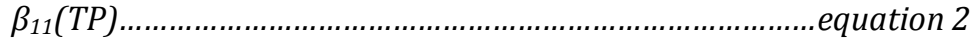

Table 3: Model summary

\begin{tabular}{lllll}
\hline Model & $\mathbf{R}$ & $\mathbf{R}^{\mathbf{2}}$ & Adjusted R Square & Std. Error of estimate \\
\hline 1 & $.912^{\mathrm{a}}$ & .832 & .818 & .380 \\
\hline
\end{tabular}

a. Dependent variable: Consumer buying behaviour

As reflected in Table 3, the $\mathrm{R}$ is multiple correlation coefficient and its value is 0.912 , while adjusted $\mathrm{R}^{2}$ shows the ratio of interdependence. The value of adjusted $\mathrm{R}^{2}$ is 0.818 implying that $81.8 \%$ of the variance in the dependent variable can be predicted from independent variable.

Table 4: Coefficients

\begin{tabular}{llllll}
\hline Model & \multicolumn{2}{l}{$\begin{array}{l}\text { Unstandardized } \\
\text { coefficients } \\
\text { B }\end{array}$} & $\begin{array}{l}\text { Std. Error } \\
\text { Standardized } \\
\text { coefficients } \\
\text { Beta }\end{array}$ & t & Sig \\
\hline (Constant) & -1.216 & .276 & & -4.221 & .000 \\
Colour of packaging (CL) & .169 & .056 & .137 & 3.042 & .003 \\
Size and shape (SS) & .108 & .083 & .172 & 3.241 & .514 \\
Graphics (GP) & .212 & .074 & .224 & 4.373 & .000 \\
Packaging material (PM) & .281 & .975 & .291 & 2.154 & .745 \\
Packaging technology(PT) & .119 & .075 & .159 & 3.385 & .001 \\
Nutritional information & .174 & .917 & .174 & 2.517 & .981 \\
(NI) & & & & & \\
\hline
\end{tabular}




\begin{tabular}{llllll}
\hline Label information (LI) & .159 & .095 & .159 & 3.381 & .001 \\
Country of origin (CO) & .214 & .043 & .205 & 3.414 & .061 \\
Brand name (BN) & .251 & .062 & .261 & 3.576 & .001 \\
Consumer perceptions & .182 & .041 & .152 & 2.418 & .451 \\
Level of involvement (IL) & .156 & .085 & .114 & 2.678 & .005 \\
Time pressure (TP) & .186 & .047 & .232 & 4.275 & .000 \\
Individual characteristics & .241 & .082 & .185 & 3.524 & .642 \\
\hline
\end{tabular}

Therefore, given the results in Table 4 above, the equation is presented as follows: Consumer Buying Behaviour $=-1.216+0.169(C L)+0.212(G P)+0.119(P T)+0.159(L I)+0.251(B N)+.0156(I L)+$ $0.186(\mathrm{TP})$...... equation 3

The results show that only 7 predictor variables are significant to influence consumer buying behaviour in this study at less than 5\% significance level. These are colour, graphics, packaging technology, label information, brand name, time pressure and level of involvement. The discussion of these explanatory variables and how they influence on consumer buying for convenience goods follows below.

- Colour of packaging: Colours bring strong symbolic significance and impacts consumers' psychological and visual feelings (Wu, Bao, Song \& Hu,2009). Moreover, consumer moods can be changed by colour (Kauppinen-Raisanen \& Luomala, 2010). In this study, colour of packaging (CL) positively and significantly influence consumer buying behaviour, with a coefficient value of 0.169 and significance level of 0.003. The results concur to findings by Alervall and Saied (2013) which reveal that colour was the main visual element significantly influencing consumer emotions.

- Graphics: Graphics create an image on the packaging (Lee, 2010). Moreover, putting an image of the product on convenience goods creates a positive attitude towards the package and brand beliefs. In this study, consumer buying behaviour is positively influenced by graphics as revealed by a coefficient value of 0.212 and a significance level of 0.000 . The importance of graphics has been acknowledged by Mizutani et al. (2010) that customers will positively remark a product if the image is congruent and pleasant. Similarly, Mizutaniet al.(2010) reiterate that graphics significantly influence flavour evaluation and ultimately, consumer buying behaviour.

- Packaging technology: An innovatively designed wrapper or container can have a large impact on whether or not a product is noticed on store shelves (Agyeman, 2014), implying that technology can be a major factor that influences consumer buying behaviour. In this study, packaging technology (PT) positively and significantly influence consumer buying behaviour, with a coefficient value of 0.119 and significance level of 0.001 . A study by Sioutis (2011) also reveal that technology in packaging which represents convenience is the most significant element in influencing buying decisions.

- Label information: Most consumers feel that it is essential to read label information on the package so that they can see instructions, expiry dates, storage etcetera (Adam \& Ali 2014). In this study, consumer buying behaviour is positively influenced by label information (LI) as revealed by a coefficient value of 0.159 and a significance level of 0.01. Mutsikiwa et al. (2013)and Butkeviciene, Stravinskiene and Rutelione(2008) also argue that label information is the most significant verbal element when evaluating products before. Moreover, research by Karimi, Mahdieh and Rahmani (2013) also show that there is a significant relationship between consumer purchase decision and the label information on packaging. Thus, these findings reiterate the importance of label information on packaging on influencing consumer buying behaviour.

- Brand name: Brand name is very essential in consumers' decision making process. Nowadays, brands represent the company and also have a strong association with perceived quality, taste, social class and consumers' life style (Kariuki \& Karugu, 2014). The importance of brand name (BN) has been revealed in this study as it was found to positively and significantly influence consumer buying behaviour, with a coefficient value of 0.251 and significance level of 0.001 . Previous study by Shehzad, Ahmad, Iqbal, Nawaz and Usman (2014) reveal that brand name has a significant positive relationship with consumer buying behaviour. The authors further argue that consumers are brand conscious and prefer branded products. 
- Level of involvement: According to Maiksteniene and Auruskeviciene (2008) convenience goods are generally regarded as low involvement but consumers' involvement varies with every consumer. This gives some direction to how level of involvement can influence consumer buying behaviour. In this study, consumer buying behaviour is positively influenced by level of involvement (IL) as revealed by a coefficient value of 0.156 and a significance level of 0.005 . This is supported by Chavis (2010) who states that the degree of involvement has a very significant effect on consumer behaviour.

- Time pressure: Kuvykaite et al. (2009) describe time pressure as having too little time to do purchasing. This therefore suggests that, overall, it influences consumer buying decisions. The results of this study revealed that time pressure (TP) significantly influences the purchasing decision of convenience goods as reflected by a coefficient of 0.186 and a significance level of 0.00 . A study by Silayoi and Speece (2007) concluded that time pressure is a significant factor in influencing consumer buying behaviour. The explanation for this finding could be based from the fact that the study mainly focused on students who are already time-constrained, thus make their buying decision based on the time available to them.

\section{Conclusion and Recommendations}

The findings of the regression analysis revealed a significant relationship between consumer buying behaviour and seven predictor variables; colour, graphics, packaging technology, label information, brand name, time pressure and level of involvement. The results, thus, present an insight to marketers that they should understand their consumer base and packaging factors that influence their buying behaviour and the different contexts those consumers are in. This will help marketers to focus their resources on key drivers of package, so that resources can be effectively utilised. Marketers must design colourful package because customers are drawn to a product by its colour. Marketers must design packages that do not cause any harm to the environment. It is also the responsibility of marketers to create consumers' awareness towards the environment and build consumers' responsibility toward it. Manufacturers must include information which is readable and easy to understand on package because some customers want to read the label information; use instructions, ingredients, weight and expiry date before they purchase the product. Manufacturers must avoid using dense font which is unreadable. It can be concluded that packaging elements influence consumer buying behaviour differently depending on context and on product. Some packaging elements influence buying decisions while others did not but it does not mean that they are not necessary. If all packaging elements are properly combined the package will grab customers' attention. In summary, package must be viewed as the most valued tool in today's marketing.

\section{References}

Adam, M. A. \& Ali, K. (2014). Impact of Verbal Elements of Packaging of Packaged Milk on Consumer Buying Behaviour. International Journal of Business and Social Science, 5(11),118-160.

Agyeman, C. M. (2014). Consumers' Buying Behaviour Towards Green Products: An Exploratory Study. International Journal of Management Research and Business Strategy, 3(1), 1-22.

Ahmadi, G., Bahrami, H.R. \& Ahani, M. (2013). An Investigation of Visual Components of Packaging on Food Consumer Behaviour. Business and Economics Research, 3(2), 1-11.

Alervall, V. \& Saied, J. S. (2013). Perspectives on the elements of packaging design: A Qualitative Study on the Communication of Packaging. MBA, Blekinge Institute of Technology.

Ares, G., Besio, M., Gimenez, A. \& Deliza, R. (2010). Relationship between involvement and functional milk desserts intention to purchase: Influence on attitude towards packaging characteristics. Appetite, 52(2), 298-304.

Brosekhan, A. A. \& Velayutham, C. M. (2014). Consumer Buying Behaviour - A Literature Review. Journal of Business and Management, 3(5), 8-16.

Butkeviciene, V., Stravinskiene, J. \& Rutelione, A. (2008). Impact of consumer package communication on consumer decision making process. Engineering Economics, 4(1), 57-65.

Chavis, J. C. (2010). Involvement Level and Effect on Buyer Decision Making (online). Available: http://www.brighthub.com/money/personal-finance/articles/71493.aspx (Accessed 21 June 2015). 
Du Plessis, P.J., Rousseau, G. G., Boshoff, C., Ehlers, L., Englebrecht, M., Joubert, R. \& Sanders, S. (2011). Buyer behaviour: understanding consumer psychology and marketing. $4^{\text {th }}$ ed. Cape Town: Oxford University Press.

Esitiri, M., Hasangholipour, T., Yazdani, H., Nejad, H. J. \& Rayej, H. (2010). Food product consumer behaviours: The role of packaging elements. Journal of Applied Sciences, 10(7), 535-543.

Gilaninia, S., Ganjinia, H. \& Moradi, S. (2013). Effect of Packaging Elements on Consumer Purchasing Decisions (Case Study Detergent Market). Universal Journal of Management and Social Sciences, 3(8), 10-15.

Hollywood, L., Wells, L., Armstrong, G. \& Farley, H. (2013). Thinking outside the carton: attitudes towards milk packaging. British Food Journal, 115(6), 899-912.

Jafari, S., Nia, M. S., Salehi, M. \& Zahmatkesh, R. (2013). Influence of package on consumer behaviour. Journal of Business and Management Review, 2(6), 65-71.

Karimi, P., Mahdieh, O. \& Rahmani, M. (2013). The Study of Relationship between Packaging Elements and Purchase Behaviour: Consumers of Food, Cosmetics and Health Products. Interdisciplinary Journal of Contemporary Research in Business, 5(3), 281-295.

Kariuki, A. K. \& Karugu, W. N. (2014). Factors influencing consumer purchase decisions of non-edible products in supermarkets in Nairobi Central Business District. International Journal of Social Sciences and Entrepreneurship, 1(10), 406-420.

Kauppinen-Raisanen, H. \& Luomola, V. (2010). Exploring consumers' product-specific colour meanings. Qualitative Market Research (online), 13(3), 287-308. Available: http://www.emeraldinsight.com.dutlib.dut.ac.za/journals.htm?articleid=1864412 $\quad$ (Accessed 4 March 2015).

Kotler, P. \& Keller, K. (2012). Marketing Management 14th ed. London: Pearson Education.

Kuvykaite, R., Dovaliene, A. \& Navickiene, L. (2009). Impact of packaging elements on consumers purchase decision. Economics and Management, 14(3), 441-447.

Lake, L. A. (2009). Consumer behaviour for dummies. Indiana: Wiley Publishing.

Lee, W. L. (2010).The influence of packaging attributes on consumers' purchase decision of packaged food. MBA. Sains University.

Maiksteniene, K. \& Auruskeviciene, V. (2008). Manufacturer and retailer brand acceptance under different levels of purchase involvement. Engineering Economics, 3(1), 90-96.

Metcalf, L., Hess, J. S., Danes, J. E. \& Singh, J. (2012). A mixed-methods approach for designing market drivenpackage. An International Journal of Qualitative Market Research, 15(3), 268-289.

Mizutani, N., Okamoto, M., Yamaguchi Y., Kusakabe, Y., Dan, I. \& Yamanaka, T. (2010). Package images modulate flavor perception for orange juice. Food Quality and Preference, 21(7), 867-872.

Muruganantham, G. \& Bhakat, R. S. (2013). A Review of Impulse Buying Behaviour. International Journal of Marketing Studies, 5(3), 149-160.

Mutsikiwa, M., Marumbwa, J. \& Mudondo, D. C. (2013). The Impact of Informational Package Elements on Consumer Purchase Behaviour of Breakfast Cereal Products: The Case of University Students in Masvingo, Zimbabwe. European Journal of Business and Management, 5(8), 55-63.

Phillips, S. \& Bradshaw, E. (2011). The influence of visual packaging design on perceived food quality, value and brand preference. International Journal of Retail and Distribution Management, 41(10), 805-16.

Rizvi, S. \& Elahi, Y. A. (2013). A study of consumer behaviour regarding "durable goods" in Lucknow region. International Journal of Applied Services Marketing Perspectives, 2(3), 535-544.

Salahshour, A. \& Feyz, D. (2010). Application of the golden ratio in the package of goods and its impact on consumer purchase behaviour. Journal of Business Administration, 2(6), 113-134.

Schiffman, L. G. \& Kanuk, L. L. (2007). Consumer behaviour. 9th Ed. New Jersey: Pearson.

Shehzad, U., Ahmad, S., Iqbal, K., Nawaz, M. \& Usman, S. (2014). Influence of Brand Name on Consumer Choice and Decision. Journal of Business and Management, 16(6), 72-76.

Silayoi, P. \& Speece, M. (2004). Packaging and Purchase Decisions: An exploratory study on the impact of involvement and time pressure. British Journal (online), 106(8), 607-628. Available: http://search.proquest.com.dutlib.dut.ac.za/docview/225141612 (Accessed 2 February 2015).

Silayoi, P. \& Speece, M. (2007). The Importance of Packaging Attributes: A Conjoint Analysis Approach. European Journal of Marketing (online), 41(12), 1495-1517. Available: http://www.emeraldinsight.com.dutlib.dut.ac.za/journals.htm?articleid=1634375 (Accessed 4 May 2015). 
Sioutis, T. (2011). Effects of Packaging Design on Consumer Expectations of Food Product Healthiness. MSc, University of Aarhus.

Tavakol, M. \& Dennick, R. (2011). Making sense of Cronbach's alpha. International Journal of Medical Education, 2(1), 53-55.

Tustin, D. H., Lingthelm, A. A., Martins, J. H. \& van Wyk, H. J. (2005). Marketing research in practice. Unisa Press: South Africa.

Venter, K., Merwe, D. V., Beer, H. D., Bosman, M. \& Kempen, E. (2011). Consumers' perceptions of food packaging: an exploratory investigation in Potchefstroom, South Africa. International Journal of Consumer Studies, 3(5) 273-281.

Warlop, L., Ratneshwar, S., Osselaer, V. \& Stijn M. J. (2005). Distinctive Brand Cues and Memory for Product Consumption Experiences. International Journal of Research in Marketing, 22(1), 27-44.

Wells, L. E., Farley, H. \& Armstrong, G. A. (2007). The Importance of Packaging Design for Own-Label Food Brands. International Journal of Retail and Distribution Management (online), 35(9), 677-690. Available: $\quad$ http://www.emeraldinsight.com.dutlib.dut.ac.za/journals.htm?articleid=1617096 (Accessed 1 March 2015).

Wills, J. M., Schmidt, D. B., Pillo-Blocka, F. \& Cairns, G. (2009). Exploring global consumer attitudes toward nutrition information on food labels. Journal of Nutritional Review, 2(5), 103-112.

Wu, P., Bao, Z., Song, W. \& Hu, Z. (2009). Research on semantics of packaging design. In Computer-Aided Industry Design and Conceptual Design, 3(1), 316-318.

Zeyghami, M., Rezaei, S., Asadi, S. S. \& Davoodabadi, A. (2011). The role of technology assumption on consumer behaviour: A case study in Food industry. Journal of Food Science and Industry, 8(1), 49-54. 